\title{
HISTORY AND SELF-REALISATION: A NEW HISTORICAL READING OF HARUKI MURAKAMI'S THE WIND UP BIRD CHRONICLE
}

\author{
ANUPAMA. A \\ Research Scholar, Department of English, Vimala College, Thrissur, Kerala, India
}

\begin{abstract}
Alienation from society and search for self characterise Murakamian literary world. The selected novel, The Wind Up Bird Chronicle truly captures the dilemma of post-war industrially advanced society which suffers loss of meaning and purpose in life. Return to past works as one of the main theme in the novel and it makes the current paper to vest its interest in history. It focuses on the marginalised historical events of World War II which are presented directly and remains as an active presence throughout the novel. The research paper shows a New Historical reading of the novel and how it enables the characters' self-realisation. It explores the historical amnesia of contemporary Japanese society by emphasising the inevitable existence of past in present lives.
\end{abstract}

KEYWORDS: History, New Historical reading, self-realisation, alienation, historical amnesia

Received: Oct 06, 2020; Accepted: Oct 26, 2020; Published: Dec 07, 2020; Paper Id.: IJELOCT20203

\section{INTRODUCTION}

Search for the meaning of one's own existence is a recurring theme in Murakamian literary world. The 1960's children including Haruki Murakami have been brought up in the background of the nation's fall due to its defeat in World War II and subsequent atomic attacks. This resulted in the total destruction of an ambitious and capitalised nation into nothingness. The succeeding generation were the victims of War but instead of crying pathetically of the lost glory, they were taught the intelligent ways to regain the wealth and reputation of their nation. They worked hard, became systematic, disciplined and concentrated on the single aim of the revival of Japan as a powerful nation. The economic boom showed its benefits in all fields and the life of people began to change. But the "Lost Generation" was unable to assimilate them into the newly developed high capitalist culture. Paranoia, desperation and schizophrenia haunted them throughout their life. Writers like Murakami understood the dilemma faced by Japanese society in the midst of technological advancements and highly mechanised living.

Murakami's concern with the truthful presentation of history leads him to the extent of accusing the Japanese authorities for concealing the war time cruelties conducted by Japanese soldiers towards the Chinese, Koreans and Russians. The 'comfort women' (Russian women who were kept as prostitutes for fulfilling the carnal needs of Japanese army), the Nanking Massacre, poisoned gas killings are some of the examples of war time atrocities. Japanese cruelty is brilliantly hidden from historical documents and is never discussed in any educational institutions or academic circles. But Murakami strongly believes that Japan still bears the shame on its back and in the press conference in Tokyo in 2015, he requests the nation to apologise whole heartedly for the its earlier cruel deeds. He calls for historic revisionism and tells, "The issue of historical understanding carries great significance, and I believe it is important that Japan makes straightforward apologies." (The Straits Times, 2015) 
Murakamian experiments with seeking reality and delineating its disappearance become significant by analysing it from the dilemma of contemporary generation. The writer uses several devices like history, memory, dreams, inner consciousness, images and mysticism for the purpose. He stresses the notion of "historical amnesia" which is deliberate forgetfulness of history while living in a profit oriented material world. Almost all his works, in one way or the other emphasises the relevance of historical awareness and war memory in individuals' life. His novels like, Kafka on the Shore, A Wild Sheep Chase and IQ84 have direct references to historical events and characters. In his 2003 novel, The Wind Up Bird Chronicle, he presents the experiences of Second World War and its effects in the lives of his characters in contemporary society. He addresses the textuality of history and the historicity of texts which is the prerequisite element of New Historicism. The marginalisation of war time events and experiences are brought into light with the help of the character Lieutenant Mamiya who served the Japanese troop in the Battle of Nomonhan. The battle couldn't find a significant place in the history books because it brought shame to the Japanese government causing the death of several soldiers without any benefit. Many atrocities committed by the army against China, Korea, Philippines, Indonesia and other Asian nations are put into discussion several years after the war through the novel. It reminds the famous Tokyo Trials conducted from 1945 to 1947 during the time of MacArthur sentencing many Japanese higher authorities for being warmongers. Murakami knows that history is not something about past but it is deeply connected with the present and foresees future. He shows how history which is forgotten by the post war generation plays the guiding role in the lives of ordinary people represented by Toru Okada, the protagonist of the novel. It leads him to his inner consciousness and realises his inner potentials to resolve personal problems.

\section{METHODOLOGY}

Murakami realises the inevitability of past events in deciding one's present and future. The post-war generations, devoid of any direct war memories have to learn about it from historical records, official documents, journals and history books. Foucauldian and Gramscian arguments on the circulation of power and its ideological domination have questioned the reality and genuineness of historical facts and records. Marginalisation of several incidents and people are implied factors in any history book. Historical records are subjective expressing the politics of the author, the time in which it is written and also satisfying the dominant power. Old historical reading considers history as the context or background to the text just like simply viewing the depiction of Elizabethan society in Shakespearian dramas. The idea whether Elizabethan society shaped Shakespearean literary domain or Shakespeare's works moulded Elizabethan society points out the interconnectedness between literature and history. The relationship between both is intertwined and can't be looked upon as separate entities as happened in old historical reading.

Conventionally, history was viewed on the basis of the stories of great men and unifying principles without any dissent. But New Historicism offers a novel view of seeing history as a human construct devoid of naturality, objectivity and authenticity. It gave ear to conflicting ideas, attitudes, movements and visions and addressed subversive, anarchic and counter movements of the age. There was a wide recognition in the 1970's and 80's that texts are to be read from the socio cultural conditions in which they are placed. Literature became historical and history became literary. New historicism reflects on the production of history by power centres and how institutional and social power relations decide the history and narratives of the age. It became a critical movement after the publication of Stephen Greenblatt's Renaissance Selffashioning: From More to Shakespeare in 1980. It is a reaction against the ahistorical and synchronic character of poststructuralist discourses. In his study of the Elizabethan literary period based on the socio cultural significance of the 
time, he views how the Tudor dynasty of the time supported monarchy and fuelled class distinctions and maintained gender roles.

Stephen Greenblatt argues the new historical reading of considering both history and literature as co-texts instead of history as context. His essay, "Shakespeare and the Exorcists" rereads the religious and socio-political happenings of the time as expressed in Samuel Harsnett's book, A Declaration of Egregious Popish Impostures published in 1603, on the exorcisms conducted by the Catholic priests in Buckinghamshire in 1580's. While the Anglican Harsnett accused Catholic Church as a theatre and drove away all the spirits, Shakespeare welcomed them to his stage. Greenblatt finds the effect of the book and the exorcisms conducted by the Catholic and Puritan priests of the time in Shakespeare's plays like King Lear, Twelfth Night, A Midsummer Night's Dream etc. But Shakespeare dealt with them not as mere backgrounds but immersed them as co-texts. His purpose was neither to deceive people nor to promote Catholicism but for the higher aim of theatre as representation of human lives. Greenblatt emphasises the interconnectedness between history and literary work with a differential reading. In an advanced capitalist society, he is concerned with the problematic relationship between individual self and its social performance in a capitalist regime. He tells that as a part of 'improvisation' which is unavoidable when an individual enters the power system, his identity is transformed into a fiction. As a social being, he gets adapted to the system and loses the ability to resist. Even resistance reinforces the circulation of power. Refuting the popular notions of self-fashioning and dominant aspects of self- representation is an important aim of New Historicism.

New Historical discourse goes beyond the text's manifested content and crosses the boundaries of canonical view of considering a text. It is based on the belief that a text is not an autonomous entity; instead, it has several functions to perform. It moves from the semantic content of the text to the idea of text as practice. (Colebrook, 28) Despite viewing a literary text from its 'signified' concept, the discourse enquires how the text works in relation to various other factors. It applies a deeper hermeneutic strategy. Giving importance to the socio-cultural and historico-political aspects on which a literary text is located, the discourse enhances the worth of literature. By reading of both literary and non-literary texts together New Historicism focuses on what exists in and around the text. Providing opportunities to re-imagine and reinterpret historical events, the discourse calls our attention to the fact that human life is largely related with past events. It celebrates the reading of past from the present and interrogates the power relations operating within a society by shifting from text into context.

According to new historicists, "Questions are not directed to what lies beneath the text but to those other texts and events which surround the work. The answers to such questions are necessarily multiple given the various situations in which a text can be read and performed, as well as the various historical events to which the work can be considered adjacent." (Colebrook, 207) Multiple functions of a text are given importance which help effectively in new ways of thinking about history. Greenblatt sees history as a medium of power involving several conflicts, plots and exclusions. History is textually determined and can be analysed by the recognition of power, culture and other non-textual aspects. "The textualisation of history, as well as an attempt to think beyond history as text, is perhaps the clearest identifying feature of new historicism." (Colebrook, 220) He criticises Jameson and Lyotard for postmodern theories' failure to consider the historical aspects of literary texts. New historicism in this way is a return to history and its interpretations. Both Greenblatt and Louis Montrose speak about the formalist nature of post-structuralism which is antihistoric. It is concerned with how meanings are produced in the present by the repetition of signs from the past which Greenblatt calls 'resonance' (Colebrook, 230) It refuses to see text from a predecided or stable context and history as a discourse of 
singular line of progress. A rethinking of history and historiography become possible through the New Historical discourse. Historical consciousness is unavoidable in the development of man and society. It fills the gap between present and past by giving the concept that present is not just a continuation of past but men of letters can interpret and investigate past to make it comprehensible for the present. New historicism views history from a different perspective which is a horizon of truth and meaning rather than a series of events.

\section{History and The Wind Up Bird Chronicle}

The protagonist of the novel, Toru Okada finds himself against self-fashioning which is the submission of one's self by clinging into socio economic standards. Toru's temperament is different from an ordinary material man who works for his family, obeys the demands of capitalist system and reduces to the level of a mere sign without authenticity. Instead, he sees the world in all its simulation, recognises its true nature and finds his difficulty to cope up with its mechanical ways. This is clear from his resignation from job as a lawyer's assistant only because he found it boring and meaningless. This type of mentality keeps him aloof from society but works as a blessing in disguise enabling him to look at things from a different point of view. He neither curses his wife for leaving him without any note nor runs for another woman to fill her place. His love for Kumiko attains a more genuine level after her disappearance and he begins to think of her as an independent individual with her own thoughts and emotions. He realises that he hasn't understood the real Kumiko even though they shared life for years. Toru's search for Kumiko is intervened and directed by other characters like May, the Kano sisters, Mamiya, Noboru Wataya, Nutmeg, and Cinnamon. All of them help him in various ways and among them Lieutenant Mamiya acts as the connector between Toru and historical events. His presence and narration of events in epistolary manner opens up the protagonist's mind. He identifies himself with Mamiya and this empathy leads him to truth. By internalising Mamiya's experiences Toru too becomes a part of history who is otherwise disillusioned with his nation. He attains self-realisation by historical awakening.

Murakami in the novel presents the deliberately forgotten and marginalised events of World War II in the history of Japan. The inhuman nature of war and ruthless power mongers playing behind it are severely criticised in the text. The novel apparently gives a subversive view of war different from the lens of hyper nationalism. Soldiers are forced to join army and taught to fight for their nation even at the scarcity of necessary arms and ammunition. They are forced to accept that fighting for their nation without complaining provides martyrdom leading to their submission without resistance. The real cause of war is unknown to them and they are placed in the dilemma of differentiating between friends and foes. Sergeant Hamano who joins the group for the secret mission at Manchuria openly states about the worthlessness in waging endless wars. He understands that it doesn't benefit any nation. Soldiers are destined to kill many innocent civilians as the enemies hide among the civilian population by taking off their uniforms. Lack of food and water and difficulty of keeping the prisoners leads to unscrupulous killing. Hamano is every bit a soldier who is never afraid of fighting and is ready to sacrifice life for his nation. But he genuinely feels, “I'm telling you Lieutenant, this is one war that doesn't have any Righteous Cause. It's just two sides killing each other...I can't believe that killing these people for no reason at all is going to do Japan one bit of good." (Murakami, 143)

The Wind Up Bird Chronicle, as the title indicates is an account of events not only in the lives of characters but also of the nation. It provides several instances for the mental struggle of soldiers while killing the captives. Murakami agrees with Greenblatt by showing the play of power system determining the course of war and the fate of the nation and its people. At the end of the war, soldiers are abandoned without family and self. They are filled with a vacuum which eats 
up their mind. Lieutenant Mamiya, who acts as a mentor to the Protagonist, is a living war victim. The novel shows a beautiful shift in focus from seeing history in the shoes of power centres to the marginalised participants fulfilling the perspective of new historicism. The biased views of history books which are taught in schools and is absorbed in the life of every individual is emphasised by Murakami. History is not something looked upon as a series of past events in chronological order as there is no such order according to Foucault. The relevance of history moulding both present and future becomes clear when Mr. Honda says that a person's destiny lies not in his future, but in his past. This is brought into light by showing the connection between Toru's individual self and the war time incidents which happened before his birth.

Toru, living far away from the war time happenings is affected by Mamiya's experience. His acquaintance with Mamiya happened by the intervention of Honda, the Wataya family's spiritual guide, helps him in his journey to truth. The chapters entitled as "Lieutenant Mamiya's Long Story", renders a revisiting to World War II. The Battle of Manchuria in which Japan fights with China is unfolded before the readers from an ordinary militant's perspective. Many of the Japanese army know that it is impossible to have control over such a huge country like China, but recent minor victories increases the confidence of authorities to extend their authority. War is different to both a layman and a soldier. An ordinary soldier who doesn't involve in direct battles enjoys the benefit of war; as Mamiya tells, "But living the easy life of an officer in Hsin-Ching, you almost wanted to ask, "War? What war?" We'd go out drinking and carousing every night, and we'd visit the cafes where the white Russian girls were.” (Murakami, 136) Later Mamiya is left to die in the vast desert of Manchuria when he and his group including Corporal Honda and sergeant Hamano fail in their secret mission under the leadership of Yamamoto. He witnesses man skinning leading to the loose of his consciousness. The Mongolian officer under the instruction of the notorious Russian, Boris, the man skinner takes away Yamamoto's skin just like peeling an orange by using a special knife. His loud screams haunt Mamiya throughout his life. Murakami minutely explains the skinning episode in order to provide a true picture of war time cruelties and its effect on living victims. The process ended when Yamamoto is transformed into a mere red lump of meat leaving the ground a sea of blood.

Mamiya, who was left to decay in the dried up well in the desert by the Mongolian army got saved by Honda after experiencing an aborted enlightenment. The horrific incident and his experience inside the well which he felt like another strange world give him an opportunity to think about the meaning of life. His struggled soul is caught unexpectedly in a confined area which is away from the surface of the earth where he can hear only his own heart beat, see the sunlight and taste the drops of morning dew. He feels a sort of enlightenment at the proper intervals of the sunlight showering directly into the deserted well. In both the days which he spends inside the well, he waits for the removal of darkness which happens when the sun shines straight down to the bottom and lasts only for ten or fifteen seconds. He feels complete relaxation of body and soul and his pain, loneliness and desperation melt away in the pure sunlight. "I felt I wanted to die. I experienced a wonderful sense of oneness, an overwhelming sense of unity." (Murakami, 166) The word 'wanted' is italicised in order to show the change happened to Mamiya who was afraid of dying before the commencement of secret mission. In the bright light he sees something taking shape but he can't catch it as the light disappears. He feels that "something" is his own soul and considers sunlight as the catalyst leading towards it.

Even though Mamiya feels that he is at the nearest point to reach his soul, the sudden disappearance of sunlight leaves him dejected. He is left empty minded after the incomplete experience of rejuvenation. The feeling that his life has ended and he is transformed into an empty shell wipes out all his fears of death. He proceeds by waging battles incessantly 
as he has nothing else to do. The amputation doesn't hold him back and he is taken as a war prisoner to work in Siberian mines. After the occupation of Manchuria by the Soviet troops, the Japanese prisoners are taken as labourers to work in Siberian mines. His second encounter with Boris, the man skinner in the mines provides opportunity to take revenge on him for all his cruelties. Even though, Boris Gromov is also a prisoner he enjoys special status because of his shrewdness and manipulating abilities. He cheats both Russia and those who around him for personal benefits. At the pretention of giving partial autonomy to Japanese prisoners and saving them from brutal torture, he manipulates them. He actually exercises his control over them after promising half liberty. Mamiya acts as the translator between Boris and the Japanese prisoners and he feels guilty at the real motives of the man skinner. His attempt to murder Boris fails pathetically as he is taken back by some force inside. The earlier experience of loss at the well haunts him causing diffidence. Mamiya is teased and insulted by the villain due to his weak mental power and is left dejected for the rest of his life.

This becomes a lesson to Toru when he fights with the faceless man in room number 208. Both Mamiya and Honda feel that Toru may get benefitted from what he learned from his experience. This proves to be true when he recognises that the throne of truth is inside his inner consciousness. His journey from the conscious to the unconscious is aided by the abandoned and dried up well in the neighbourhood. Use of such equipments like wells, basements, underground pathways, abandoned buildings, dense forests and escalators are common in Murakamian fictional world and they provide route for the character's self-realisation. The well seems to the protagonist, the most appropriate place away from the hullabaloo of city life to meditate upon his life. Going deep into it is like entering the labyrinth by searching for its centre. When Mamiya is forced into the well by the enemies, Boku chooses it after getting inspired by him. His journey to revelation is planned by himself and he takes all necessary preparations. He experiences the other world by crossing the cold wall of well for three times and in the final journey he fulfils his purpose. Inside the well, Toru finds himself in a hotel and a nameless woman whom he takes for Kumiko in room number 208. He converses with her and tries to connect the missing links. Toru succeeds by making the unconscious conscious that is by relating both the worlds. Alienation from the simulated society makes the process easier. He beats the villain, Noboru Wataya, Kumiko's brother with the baseball bat while in real life the politician falls into comatic state. When Mamiya fails to punish the evil, Toru learns from his experience and defeats the enemy with the newly gained knowledge.

Fraudulence, manipulation and violence connect the evils in Mamiya's and Toru's life. Noboru Wataya is a reincarnation of Boris, the man skinner. Boris destroyed the life of many in various battles. Likewise, the modern day politician Noboru adapts new ways of cheating people for fame and power. Foucault's notion about the futility of war which doesn't end any type of authoritarianism but only results in the shifting of power becomes appropriate here. Several years after the war, people are exploited and used by power structures in various ways as seen in Hegelian notion of synthesis. Noboru's popularity as an academician, economist and an author is a result of simulation and Toru recognises this earlier. He plays with the souls of people by controlling and defiling them as happened with Kumiko and Creta Kano. He causes the death of his sister and plays the same card with Kumiko. Her unusual sexual desire which is a result of his control makes her leave Toru forever. She is afraid of the Wataya blood of selfishness and violence flowing inside her and it leads her to an abortion preventing the birth of a successor with the evil blood. Finally she liberates her soul by killing Noboru in his coma stage at the hospital and it leaves her soul free. Toru's realisation of the complicated relationship between Noboru and Kumiko and his timely actions help his wife in achieving her aim. Toru learns about Wataya family's connection with war and politics which carries the history of violence and fraudulence. Noboru's uncle Yoshitaka Wataya was a business man and politician who made profit out of war. His friendship with Kanchi Ishiwara, the ring leader of 
Manchurian incident which was notorious for the staged Chinese attack on Japanese troops helped to think of the business behind waging wars. Both of them were interested in transforming Manchukuo, the puppet state created by Japanese troops into a "new model Asian nation". They concentrated in logistics and wrote about the need for increasing sheep farming and production of wool for the soldiers to meet with war during winter. The profit oriented technocrat, Yoshitaka was banned from his position after the occupation of MacArthur. But later he became a politician and a diet member and his legacy falls on his nephew, Noboru Wataya. His successor is worse than him who grabs people's souls and makes them slaves. Revisiting of past in new forms occurs in the escalation of Noboru Wataya as a diet member.

History aiding self-realisation is seen in the characters, Nutmeg and Cinnamon who helps Toru in various ways. Unlike other people they recognise that historical consciousness is linked with their personal consciousness making their life meaningful. Nutmeg's memory of the Hsin-Ching days during the World War II, the zoo where her father, the generous veterinarian was working and her escape from the dangerous place after Japan's defeat play great significance in her life. Nutmeg and her mother leave the vet behind and he gets killed later. Even though Nutmeg doesn't have any direct knowledge about the happenings in the zoo or the mental state of her father, her inner mind depicts the events one by one which created a void in her father. The zoo was her second home and she could see the changed situation in which the animals were killed brutally due to the shortage of food and the inconvenience of shifting them to another place. The doctor suffers mentally since he witnessed their liquidation of those he loved as his own children. His direct experience with death by identifying with the dying Russian soldier leaves him half-dead. Murakami not only gives the picture war time atrocities but also the inner dilemma that an ordinary being going through by witnessing inhuman activities. Brutal murdering of the Chinese and Russian captives by using bayonet and baseball bat affect the "something" inside the Vet. It is to be noticed that Toru beats his enemy with the baseball bat in the hotel room which draws a connection between past and present. More than that the Vet had a special mark on his cheek which Toru's right cheek develops after his first encounter with the other world through the well. This symbol attracts Nutmeg's attention and she seeks his aid in spiritual healing.

The world in Hsin-Ching was the real world for Nutmeg and she used those living memories in her spiritual healing. She could feel the "something" within her women customers, "All she had to do was bring to mind the story she had told Cinnamon and the scenes she had described for him. Her consciousness left her body, wandered for a while in the spaces between memory and story, then came back." (Murakami, 479) Nutmeg's narration of the zoo days to Cinnamon from his childhood days moulded his personality. He writes "The Wind Up Bird Chronicle" with real life characters like his grandfather, Toru and Kumiko in his computer which acts as his labyrinth. He has stopped talking at the age of six and decides to make use of his abilities. Nutmeg says that something which came out of the stories grabbed his sound. But it is significant to have another view that the stories he heard of his grandfather and war memories make his life meaningful. He renders his own version of history both heard from his mother and his imagination. The state of muteness helps him concentrating his own self and to escape from others' compulsion to have the monotonous life of school education, highly paid job and a lovely family. His version of history is subjective and it involves the real life of people instead of the triumph of nation and its sagas. Cinnamon understands Toru's problems without any direct communication with him and at the end of the novel Toru is saved by him from the gushing of new born water inside the well. Both mother and son find their identity in their relationship with past and it makes them help others. 


\section{CONCLUSIONS}

Murakami uses history as a tool of self realisation. Toru is the representative of a generation which is unable to find solace in any belief or motto. He struggles in the unreal world of pretentious people. Connection with past rejuvenates his self and generate positive results. Toru, in his journey to truth wonders about the connection between his personal life and history. He is connected with Cinnamon's grandfather with the newly gained large mark on his cheek which is a symbol of spiritual knowledge. The vet is linked with Mamiya by the city of Hsin-Ching and Mamiya is related with Mr. Honda due to their special military task at Manchuria. Honda is the spiritual connector of Wataya family and Toru is lined with Mamiya through Honda and his experience in the well. The land where the abandoned well is situated has another story which was earlier the property of a Japanese army officer who was notorious for killing many Chinese prisoners. Toru feels "All of these were linked as in a circle, at the centre of which stood the pre-war Manchuria, continental East Asia, and the short war of 1939 in Nomonhan." (Murakami, 498) Toru after recognising the truth behind Kumiko's disappearance and the cruelty of Noboru understands the reason for his connection with history. History is not a mere background but a direct presence in the novel. The novel carries the ambience of Second World War throughout narration. Murakami, by questioning the historical amnesia of the post-war generation, emphasises the relevance of connecting the present with the past for self-actualisation.

\section{REFERENCES}

1. Colebrook, Claire. (1997). New Literary Histories: New Historicism and Contemporary Criticism. New York: Manchester United Press

2. Greenblatt, Stephen. Renaissance Self-fashioning: From More to Shakespeare. Chicago \&London: The University of Chicago Press. Retrieved from sixteenthcentury.pbworks.com

3. Greenblatt, Stephen. Shakespeare and the Exorcists. Retrieved from minorshakespeares.files.wordpress.com

4. Hamilton, Paul. (2007). Historicism, $2^{\text {nd }}$ edition. New York: Routledge

5. Mori, Masaki. (2012). Murakami Haruki's Canon. Southeast Review of Asian Studies, 34, $215-21$

6. Murakami, Haruki. Trans. Jay Rubin. (2003). The Wind Up Bird Chronicle. London: Vintage Books

7. Richard, Chozik Matthew. De-exoticizing Haruki Murakami’s Reception. Comparative Literature Studies, Pennsylvania State University Press. 62-73.

8. Sellers, Bridget. (2017). Down the Well: Embedded Narratives and Japanese War Memory in Haruki Murakami. University of Tennessee Honours Thesis Projects. Retrieved from trace.tennessee.edu

9. The Straits Times. (2015). Apr 17. Retrieved from https://www.straitstimes.com 